\title{
LIBRARY ACQUISITIONS
}

\author{
Compiled by JANICE KRAUS
}

Ms. Kraus is a Library Associate in the Department of Special Collections and Archives, Rutgers University

The Library has acquired three volumes of Jesuit reports on their missions in the Far East. Two deal with the Society of Jesus' involvement in Japan and India, the third with its missions in China. One is the third edition of Rerum a Societate Iesu in Oriente gestarum (Baldwin Fund), the first official collection of Jesuit letters from India and Japan. It was compiled by Giovanni Pietro Maffei, the first official historian of the order, and was printed by Decius Lacchaeus (Naples, I 573). This volume is quite rare (its only other registered U.S. location is the Library of Congress), and apart from the light it sheds both on Jesuit activity in the Orient and on the efforts of Jesuit superiors to regulate the publication of letters from the mission field, it is interesting in another respect: it contains the first printed rendering of Japanese characters in a western volume (in the section Specimen quoddam litterarum vocumque iaponicarum; this is absent from the two earlier editions of the book). The second volume, Lettera annale delle cose del Giapone del M.D.L.XXXII. (Chapman/Famulener Funds) contains the letters of the Jesuit vice-provincial in Japan, Gasparo Coelho, published in Rome by Francesco Zanetti in 1585 . Here the emphasis is on Jesuit efforts to Christianize the populace and establish a native clergy. It also contains, among other things, an account of the martyrdom of five Jesuits in Selsete, and some reasons for the first Japanese embassy to the West. This last dovetails nicely with a book acquired earlier for the Library which actually chronicles this embassy: Guido Gualtieri's Relationi della venuta degli ambasciatori Giaponesi a Roma (Venice, I 586; see JRUL, June I983, "Gifts and Acquisitions"). The last acquisition in this area, De Christianae expeditione apud Sinas suscepta ab Societate Iesu, ex P. Matthai Riccii eiusdem societatis commentariu, libri $V$. (Lyon, I6 I6, Brower Fund), contains reports of Jesuit activity in China, and represents some of the earliest European commentary on that country. It was edited by Nicolaus Trigaut, the head of three Jesuit missions in China for several years. Some of the reports he included are those of 
Matteo Ricci (in China from I 582-I 600), perhaps the most illustrious of the order's representatives in China. These three volumes enhance what is a growing collection of early western reports on the Far East.

The Library has also acquired the Catechismus ecclesiae Geneuensis of John Calvin (Geneva, I550, Alexander Fund), a volume of instruction in the Calvinist faith done in a question-and-answer format, from the press of Jean Crespin. The catechism was written shortly after Calvin's arrival in Geneva in 1536 as a means to enforce Protestant doctrine there. The Library also owns a I 552 French version of the catechism, also from the press of Jean Crespin. An edition of the Poemata iuvenilia (Pruyn Fund) written by Theodore de Beza ( 5 I9-I605), Calvin's successor in Geneva, has also been acquired. These verses, epigrammata, epitaphs, etc., were written by Beza, a French classical scholar, in I 548, before his conversion and move to Geneva; they therefore have a secular character quite at variance with the religious austerity of his later writings (it should be noted that a later edition of the Poemata would also take on a more austere character). This volume is a sedecimo of 62 leaves, containing the preface used in the edition of I 548; otherwise no publication information is given. It is thought to date from around i 550 .

Other interesting European acquisitions include the Peregrinaggio di tre giovani, figuloi del re di Serendippo (D. Keese Fund), printed in Venice by Michele Tramezzino in I 557. This is a collection of oriental tales, whose translation was ascribed to the otherwise unknown Christoforo Armeno and is the first edition of a work reprinted many times and in many languages; Zee-rechten, inhoudende dat oudste en hoogste water-recht, dat de gemeene kooplieden en schippers hebben gemaakt en Wisbuy (Amsterdam, I695-I699, Hassert gift), a collection of seven tracts on maritime law, which is quite rare; An Essay on the Sea-Scurvy (Reading, 1 753, Ross Fund) by Anthony Addington, an English physician. (This treatise, even in the eighteenth century, was more a curiosity than a manual of practical value inasmuch as Addington recommended keeping water fresh at sea by the addition of hydrochloric acid!); Le petit almanach de nos grandes fermes, accompagné de quelques prédictions pour l'année 1789 (London, I 788, Silas Cook Fund); the very rare Russian Pedological Investigations, v. I-I 3, published by the Academcy of Sciences of 
the Union of Soviet Socialist Republics (Leningrad, I927; gift of J.E.F. Tedrow); Ralph Hodgson's The Last Blackbird and Other Lines (London, I 907), and A Book of Verses by William Ernest Henley (London, I 888), both acquired through the Van Deventer Fund; Pink Diamonds: A Romance Without a Story by R. Blatchford (London, I 897, Williamson Fund); and Notes on a Journey Through France by Morris Birkbeck (London, I 8 I 4, D. Keese Fund).

Three American imprints are of interest: The first of these is the first American edition of George Washington Montgomery's translation of Bernardo del Carpio (New York, I 834, Williamson Fund), a Spanish epic originally of ca. I 200, written to counter the claims in the Chanson de Roland concerning the French liberation of Spain from the Moors. Montgomery, an American diplomat in Spain, also wrote and translated works into Spanish; he is known chiefly for introducing Washington Irving's novels into Spain. The second is William Darby's A Tour from the City of New-York to Detroit (New York, I 8 I 9, Brower Fund). Darby, a geographer, wrote this after a stint as one of the surveyors in the Michigan Territory drawing up the boundary between the United States and Canada. The third newly-acquired American imprint is a new edition of Samuel Beckett's The Lost Ones (M. Goldman gift), with original drawings by Charles Klabunde. This volume, one of 250 printed, is a product of The New Overbrook Press (Stamford, Ct., I 984).

Of New Jersey interest are the following acquisitions: Sommiere Aenteckeninge ende Deductie of George Downing ('s Gravenhage, I 665, gift of G. A. Wagner), which is a report on Anglo-Dutch differences on New Amsterdam; Catalogue of the eminent A. Edward Norton Collection Formed by George H. Sargent (Metuchen, I93 I); John H. Rapp's Plan for Founding the Town of "Hermann" (published ca. I 870), a short-lived factory town in Burlington County which had a glassworks; and a volume from the press of Benjamin Franklin, Abel Morgan's Anti-Pado-Rantism (Philadelphia, I 747). Morgan, a Baptist minister in Monmouth County, wrote this tract as a defense of baptism and its administration by immersion. 